\title{
Interactions of soil moisture and plant community properties in meadows restored from abandoned farmlands on the Sanjiang Plain, China
}

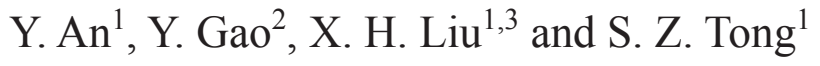 \\ ${ }^{I}$ Northeast Institute of Geography and Agroecology, Chinese Academy of Sciences; Changchun, 130102, \\ Jilin Province, China \\ ${ }^{2}$ Jilin Academy of Agricultural Science, Changchun, 130124, Jilin, China \\ ${ }^{3}$ Corresponding author.Email: liuxh@iga.ac.cn
}

Keywords: Meadow, Passive restoration, Sanjiang Plain, Soil moisture, Species diversity

\begin{abstract}
Soil moisture is a major driving force of plant community succession in restored meadows. Existing studies mainly focus on diversity-productivity relationships. However, studies which determine the effects of soil moisture on the plant community properties in restored meadows are lacking. In this study, we conducted a chronosequence analysis of the interactions between soil water content variation and plant community properties in meadows following passive restoration (3-, 5-, 9-, 14-, 17-, 21year restoration) of abandoned farmlands on the Sanjiang Plain, China. Results showed that the plant community was characterized by ruderal plants in the initial year of succession, and then by perennial plants such as Calamagrostis angustifolia and Carex spp. in older restored meadows. Similarity of restored community to target site increased across succession time whereas species diversity gradually decreased. Plant height, coverage and biomass increased with restoration time, with plant density being the exception. The community height, coverage and root/shoot ratio were positively related to the water content in the surface soil layer $(0-10 \mathrm{~cm})$. Conversely, plant density was significantly and negatively related with soil moisture at $0-10 \mathrm{~cm}$ soil depth. Plant diversity (Shannon index, Richness index and evenness) was closely correlated to soil water content at the soil depth of 0-10 $\mathrm{cm}$. Our findings indicate that vegetation of cultivated meadows could be effectively restored by passive restoration. Change of plant species diversity is an especially important response to hydrological recovery in restored meadows on the Sanjiang Plain.
\end{abstract}

Nomenclature: Editorial Committee of Flora of China (2004) for plants.

\section{Introduction}

Meadows and wetlands are characteristic ecosystems in the Sanjiang Plain of China, which were greatly influenced by anthropogenic disturbances, such as reclamation and drainage, during recent decades. Land use changes have resulted in severe degradation of both the extent and quality of these ecosystems (Huang et al. 2010). In order to reverse this trend, a series of restoration measures have been carried out through political and socioeconomic changes in the region to improve regional environment since the end of the 20th century (Zhao et al. 2008). Among these, converting cultivated farmlands to wetlands is an important approach for wetland restoration in the Sanjiang Plain (Li and Wang 2005). Afterwards, passive restoration was widely practiced in this region. However, some existing works revealed that the responses of some degraded ecosystems to passive restoration are biased towards the target (Toth 2010), presumably due to constraints imposed by changes in the loss of native species pools or shifts in species dominance (Suding et al. 2004). Thus, there is an urgent need to better understand the development of plant communities and their maintaining mechanisms of restoration succession.
It is well known that ecological restoration is the most promising strategy to reestablish the ecological structure and functions of degraded wetlands (Kirk et al. 2004, Matthews et al. 2009), wherein hydrological changes play an important role in maintaining biodiversity (Konar et al. 2013). A wide range of studies have been employed to determine how hydrologic regimes influence plant community structure in wetland ecosystems (Ellison and Bedford 1995, Casanova and Brock 2000, Baldwin et al. 2001, De Steven and Toner 2004, Johnson et al. 2004). In general, changes in species assemblage and response to hydrological recovery are difficult to predict (Grootjans et al. 1996, Härdtle et al. 2005). It was demonstrated that zonation and composition of plant communities in wet meadows are strongly related to the water regime (Loheide and Gorelick 2007). Overall, soil moisture acts as the primary constraint for plant communities in many terrestrial ecosystems (Heisler-White et al. 2008), and influences plant development and community structure. Thus, understanding the relationship between vegetation community and soil water conditions is essential for evaluating succession processes.

Although water regime determines vegetation types the most (De Steven and Toner 2004), community types and species composition often dynamically change with water-level 
fluctuations (De Steven et al. 2010). Plant communities tend to be responsive to water regimes and adapt to dynamic change more than communities linked with a relatively stable hydrology (Toogood et al. 2008). Additionally, it is suggested that uneven hydrological recovery hinders plant community recovery (Hedberg et al. 2012). Furthermore, little information is available regarding how plant communities change along with restoration succession. It was found that plant richness and diversity were higher in early restored grasslands compared to older ones (Deák et al. 2015). Also, species richness in grasslands with increasing successional age is gradually becoming more similar to that of the reference system (Valkó et al. 2017). However, environmental heterogeneity has contradictory effects on species diversity during restoration success (Ewing 2002, Biederman and Whisenant 2011). Thus, effects of soil environment on temporal variations of vegetation in restored meadows need further investigation.

Better understanding of vegetative variations and the effects of soil moisture on plant communities within spontaneously restored meadows is vital to achieve the ultimate goal of ecological restoration. Here, we conducted research in the restored meadows from abandoned arable fields on the Sanjiang Plain, China. We aimed to test the following hypotheses:

(1) After passive restoration, vegetation is generally characterized by a wide range of ruderal plants and high species diversity in the initial year, but later by perennial ones in successive years along with a decrease in species diversity (Deák et al. 2015). Thus, we hypothesized that vegetation would be characterized by ruderal plants with high species diversity in early restored meadows and by perennial plants with lower diversity in older ones.

(2) Hydrological recovery was widely reported as having a determining role in plant species diversity (De Steven et al. 2010, Konar et al. 2013). We hypothesized that the increased soil moisture could profoundly affect plant community properties and plant species diversity.

\section{Materials and methods}

\section{Research area}

The research area is located in Honghe Farmland of the Sanjiang Plain, China (Fig. 1). In this area, the climate type is temperate humid and semi-humid continental monsoon climate. The average annual rainfall is $600 \mathrm{~mm}$. The mean annual temperature is $1.9^{\circ} \mathrm{C}$. More than $70 \%$ of annual precipitation falls from June to September. The topography is dominated by plains. Meadow soil, bog soil, white soil and brown soil are dominant in this area. The main vegetation types in this area are dominated by Calamagrostis angustifolia, Phragmites australis, Carex lasiocarpa, and C. appendiculata (Wang et al. 2006).

To prevent degradation and to restore the structure and function of meadows and wetlands, a large area of farmlands were abandoned for passive restoration over the past two decades. To date, a chronosequence of restored meadows has been established for passive restoration in Honghe Farmland. There were six restored sites including 3-year (restored since 2014), 5-year (restored since 2012), 9-year (restored since 2008), 14-year (restored since 2003), 17-year (restored since 2000) and 21-year (restored since 1996) restoration (Figure 1). Additionally, a natural $C$. angustifolia meadow was selected as a reference. Each of the abandoned farmlands was cultivated since the 1980s, and corn-soybean rotation was the main cropping practice. Before reclamation, all the restored sites were typical $C$. angustifolia meadows. Passive restoration was tentatively used for reverting farmlands to wetlands. Presently, some of the restored sites are being converted to meadows or wet meadows because of long term farming and drainage during cultivation. All meadows in this study were in close proximity and had similar environmental conditions. Water levels in these meadows are regulated by groundwater connections to precipitation as well as evapotranspiration.

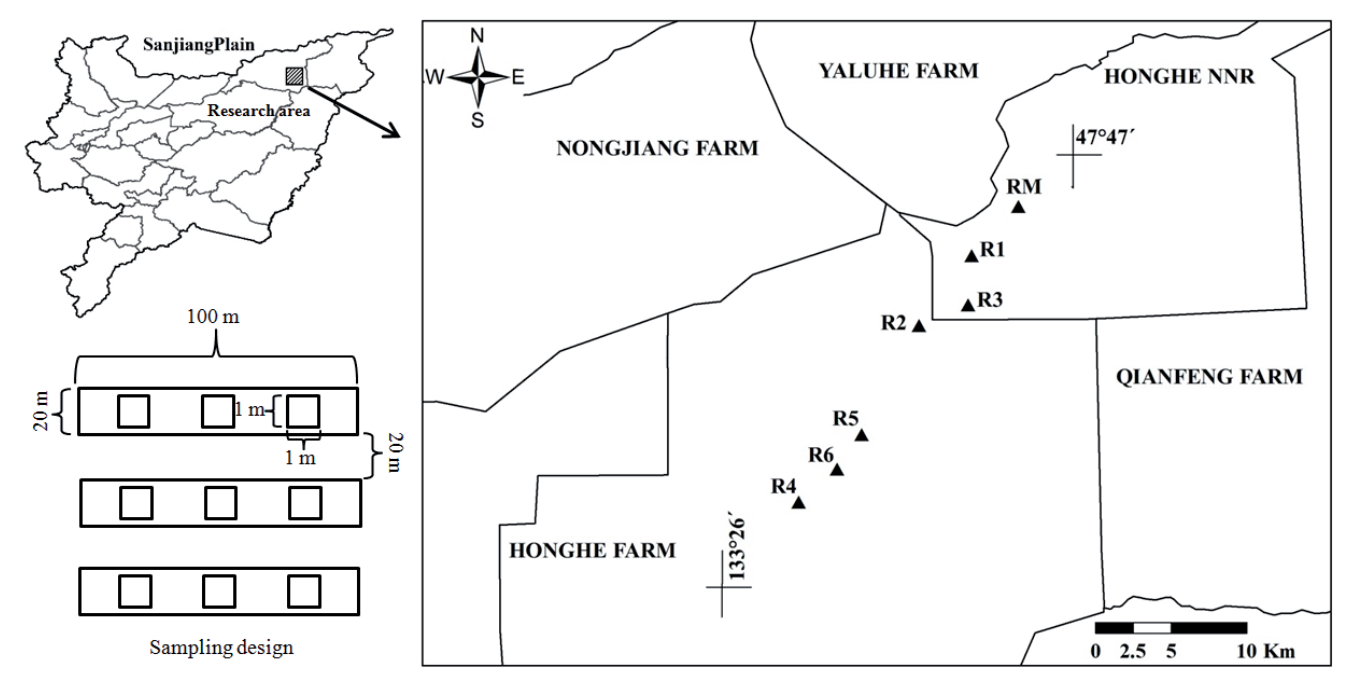

Figure 1. Location of research area and sampling design in this study. R1-6 and RM indicate 3-, 5-, 9-, 14-, 17-, 21 -year restored and reference meadows, respectively. 
Table 1. Plant species within three functional groups (forbs, grasses and sedges) in the restored and reference meadows.

\begin{tabular}{|c|c|c|c|c|c|c|c|}
\hline \multirow{2}{*}{$\begin{array}{l}\text { Functional } \\
\text { groups }\end{array}$} & \multicolumn{7}{|c|}{ Meadows } \\
\hline & $\begin{array}{l}3 \text {-year } \\
\text { restoration }\end{array}$ & $\begin{array}{l}\text { 5-year } \\
\text { restoration }\end{array}$ & $\begin{array}{l}\text { 9-year } \\
\text { restoration }\end{array}$ & $\begin{array}{l}\text { 14-year } \\
\text { restoration }\end{array}$ & $\begin{array}{l}17 \text {-year } \\
\text { restoration }\end{array}$ & $\begin{array}{l}21 \text {-year } \\
\text { restoration }\end{array}$ & Reference \\
\hline Forbs & $\begin{array}{l}\text { Artemisia argyi } \\
\text { A. scoparia } \\
\text { A. stolonifera } \\
\text { Bidens pilosa } \\
\text { Chenopodium } \\
\text { glaucum } \\
\text { Fragaria } \\
\text { orientalis } \\
\text { Gentiana scabra } \\
\text { Hypericum } \\
\text { longistylum } \\
\text { Lathyrus } \\
\text { quinquenervius } \\
\text { Lycopus lucidus } \\
\text { Lythrum } \\
\text { salicaria } \\
\text { Polygonum } \\
\text { lapathifolium } \\
\text { P. persicaria } \\
\text { Sonchus } \\
\text { oleraceus }\end{array}$ & $\begin{array}{l}\text { A. argyi } \\
\text { A. stolonifera } \\
\text { B. pilosa } \\
\text { Caltha palustris } \\
\text { C. glaucum } \\
\text { H. erythro- } \\
\text { stictum } \\
\text { Lagedium } \\
\text { sibiricum } \\
\text { L. quinque- } \\
\text { nervius } \\
\text { L. lucidus } \\
\text { Lysimachia } \\
\text { thyrsiflora } \\
\text { L. salicaria } \\
\text { P. lapathifolium } \\
\text { P. persicaria }\end{array}$ & $\begin{array}{l}\text { Achillea } \\
\text { acuminate } \\
\text { Anemone } \\
\text { dichotoma } \\
\text { A. stolonifera } \\
\text { Equisetum } \\
\text { arvense } \\
\text { F. orientalis } \\
\text { L. lucidus } \\
\text { L. thyrsiflora } \\
\text { L. salicaria } \\
\text { Salix } \\
\text { rosmarinifolia } \\
\text { Sanguisorba } \\
\text { officinalis } \\
\text { Spiraea } \\
\text { salicifolia } \\
\text { Trollius } \\
\text { chinensis }\end{array}$ & $\begin{array}{l}\text { A. dichotoma } \\
\text { A. stolonifera } \\
\text { Iris laevigata } \\
\text { L. sibiricum } \\
\text { L. quinque- } \\
\text { nervius } \\
\text { L. lucidus } \\
\text { L.thyrsiflora } \\
\text { L. salicaria } \\
\text { S. officinalis } \\
\text { S. salicifolia } \\
\text { T. chinensis }\end{array}$ & $\begin{array}{l}\text { A. dichotoma } \\
\text { A. stolonifera } \\
\text { F. orientalis } \\
\text { L. quinque- } \\
\text { nervius } \\
\text { L. lucidus } \\
\text { L. thyrsiflora } \\
\text { L. salicaria } \\
\text { S. officinalis } \\
\text { S. oleraceus } \\
\text { Stellaria } \\
\text { filicaulis }\end{array}$ & $\begin{array}{l}\text { A. stolonifera } \\
\text { L. quinque- } \\
\text { nervius } \\
\text { L.thyrsiflora } \\
\text { L. salicaria } \\
\text { S. salicifolia } \\
\text { Stachys } \\
\text { baicalensis } \\
\text { S. filicaulis }\end{array}$ & $\begin{array}{l}\text { A. dichotoma } \\
\text { L. quinque- } \\
\text { nervius } \\
\text { L. thyrsiflora } \\
\text { L. salicaria } \\
\text { S. rosma- } \\
\text { rinifolia } \\
\text { S. salicifolia } \\
\text { S. baicalensis }\end{array}$ \\
\hline Grasses & $\begin{array}{l}\text { C. angustifolia } \\
\text { C. epigeios } \\
\text { Echinochloa } \\
\text { crusgalli } \\
\text { Phragmites } \\
\text { australis } \\
\text { Poa annua } \\
\text { Setaria viridis }\end{array}$ & $\begin{array}{l}\text { C. angustifolia } \\
\text { E. crusgalli } \\
\text { Glyceria } \\
\text { spiculosa } \\
\text { P. australis } \\
\text { P. annua }\end{array}$ & $\begin{array}{l}\text { C. angustifolia } \\
\text { C. epigeios } \\
\text { G. spiculosa } \\
\text { P. australis }\end{array}$ & $\begin{array}{l}\text { C. angustifolia } \\
\text { C. epigeios } \\
\text { P. australis }\end{array}$ & $\begin{array}{l}\text { C. angustifolia } \\
\text { G. spiculosa } \\
\text { P. australis }\end{array}$ & $\begin{array}{l}\text { C. angustifolia } \\
\text { G. spiculosa } \\
\text { P. australis }\end{array}$ & $\begin{array}{l}\text { C. angustifolia } \\
\text { G. spiculosa }\end{array}$ \\
\hline Sedges & C. appendiculata & & $\begin{array}{l}\text { C. appendi- } \\
\text { culata } \\
\text { C. lasiocarpa }\end{array}$ & $\begin{array}{l}\text { C. appendi- } \\
\text { culata } \\
\text { C. lasiocarpa }\end{array}$ & $\begin{array}{l}\text { C. appendi- } \\
\text { culata } \\
\text { C. lasiocarpa }\end{array}$ & $\begin{array}{l}\text { C. appendi- } \\
\text { culata } \\
\text { C. lasiocarpa }\end{array}$ & $\begin{array}{l}\text { C. appendi- } \\
\text { culata } \\
\text { C. lasiocarpa } \\
\text { C. meyeriana }\end{array}$ \\
\hline
\end{tabular}

\section{Data collection}

On July 20, 2017, vegetation investigation was conducted using quadrat survey method in the restored meadows. Three sampling sites were chosen in each of the six restored meadows. Three equal-sized transects of $100 \mathrm{~m}$ length and $20 \mathrm{~m}$ width were established in each sampling site (Fig. 1). Within each transect, 3 quadrats $(1 \mathrm{~m} \times 1 \mathrm{~m})$ were selected randomly along each transect (total 9 quadrats in each meadow). In each quadrat, community height was measured using a ruler (20 plants were measured in each quadrat) and species composition was identified. Canopy coverage of the community was estimated as surface covered in vertical projection by each species and expressed as a percentage of the sampling surface (Balata et al. 2004). Plant density was determined by counting the number of individuals within each quadrat. All green plants from the entire quadrat were cut at ground level, and then collected. To determine belowground biomass, one subquadrat $(30 \mathrm{~cm} \times 30 \mathrm{~cm})$ was selected in each quadrat and excavated at soil depth of $30 \mathrm{~cm}$, dried and crushed to pass through a 2-mm sieve for isolation of the largest number of roots within each sample. Fine roots which remained in the soil samples were further isolated by spreading the samples in shallow trays and overfilling the trays with distilled water. The outflow from the trays was allowed to pass through a 0.5 $\mathrm{mm}$ mesh sieve. All the aboveground parts and the isolated roots were oven-dried at $65^{\circ} \mathrm{C}$ to constant weight.

To measure soil moisture, a soil auger was used to take three soil samples for each depth of 0-10, 10-20, and 20-30 $\mathrm{cm}$ within each quadrat. Samples taken at each soil layer were weighed. All soil samples were then oven-dried at $105 \pm 2^{\circ} \mathrm{C}$ for over $24 \mathrm{~h}$ and weighed.

\section{Data analyses}

To compare the similarity of species composition among meadows (including restored and reference meadows), the Jaccard Index was used. The similarity is determined as follows:

Jaccard similarity $(J)=c /\left(n_{1}+n_{2}+c\right)$

where $\mathrm{c}$ is the number of species common to both sites, $\mathrm{n}_{1}$ and $\mathrm{n}_{2}=$ the number of species found only in site 1 and 2, respectively.

Plant species diversity indexes were examined based on vegetation data. Shannon diversity index $(\mathrm{H})$, Richness index (R) and Evenness index (E) were calculated as:

Shannon diversity index $(H)=-\sum_{i} p_{i} \log p_{i}$

Richness index $(\mathrm{R})=(\mathrm{S}-1) / \ln \mathrm{N}$

Evenness index $(E)=H / \operatorname{lnS}$ 
Table 2. Jaccard similarity of plant communities in restored and reference meadows.

\begin{tabular}{|c|c|c|c|c|c|c|}
\hline Meadows & $\begin{array}{c}5 \text {-year } \\
\text { restoration }\end{array}$ & $\begin{array}{c}\text { 9-year } \\
\text { restoration }\end{array}$ & $\begin{array}{c}\text { 14-year } \\
\text { restoration }\end{array}$ & $\begin{array}{c}17 \text {-year } \\
\text { restoration }\end{array}$ & $\begin{array}{c}\text { 21-year } \\
\text { restoration }\end{array}$ & Reference \\
\hline $\begin{array}{l}3 \text {-year } \\
\text { restoration }\end{array}$ & 0.25 & 0.17 & 0.17 & 0.18 & 0.15 & 0.11 \\
\hline $\begin{array}{l}\text { 5-year } \\
\text { restoration }\end{array}$ & & 0.18 & 0.20 & 0.19 & 0.18 & 0.14 \\
\hline $\begin{array}{l}\text { 9-year } \\
\text { restoration }\end{array}$ & & & 0.28 & 0.27 & 0.24 & 0.22 \\
\hline $\begin{array}{l}14 \text {-year } \\
\text { restoration }\end{array}$ & & & & 0.26 & 0.24 & 0.23 \\
\hline $\begin{array}{l}17 \text {-year } \\
\text { restoration }\end{array}$ & & & & & 0.26 & 0.24 \\
\hline $\begin{array}{l}21-y e a r \\
\text { restoration }\end{array}$ & & & & & & 0.27 \\
\hline
\end{tabular}

where $\mathrm{p}_{\mathrm{i}}$ is the density proportion of species $\mathrm{i} ; \mathrm{S}$ is the total number of species observed in restored community; $\mathrm{N}$ is the sum of individuals over all species.

Analysis of variance (ANOVA) was used to assess the differences in community properties of restored meadows. Multiple comparisons were carried out using the LSD test at $\mathrm{P} \leq 0.05$ level. Linear regressions were performed to identify the correlations between soil water content and community properties, as well as plant diversity (Shannon index, Richness index, Evenness index). Coefficient of determination $(\mathrm{R})$ of linear regression at the $\mathrm{P} \leq 0.05$ level was considered significant. All the statistical analyses were performed using SPSS Version 16.0 (SPSS, Chicago, IL, USA).

\section{Results}

Plant community properties in the restored and reference meadows

Plant species in the communities were divided into three functional groups, forb, grass and sedge. Data of vegetation composition showed the communities in the early stage of natural succession were dominated by forbs (Table 1). There were 14 forb species in the 3-year and 5-year restored meadows, such as Artemisia spp., Bidens pilosa, Chenopodium glaucum and other ruderal plants. As the successional age increased, annual ruderal plants gradually disappeared, and the community was progressively dominated by perennials such as $C$. angustifolia, Carex spp. Likewise, the community in the reference site was characterized by $C$. angustifolia, Carex spp. and other perennials.

The Jaccard similarity of 3-year and 5-year restored meadows was 0.25 (Table 2). The communities with shorter succession ages had lower similarity to the reference meadow. The similarity of the restored meadows to the reference system increased in older restored meadows. Jaccard Index of the 21-year restored meadow to the reference site was 0.27 .

There are significant differences in the plant community properties among restored meadows (Table 3). Plant height was the lowest in the 3-year restored meadows, and reached the highest level in 21-year old and reference ones. There was no significant difference in plant height in meadows with 5-, 9- and 14-year restoration. There was no significant difference in coverage between 21-year restored and reference meadows. However, plant density in restored meadows changed conversely, the highest level, 1714 plants per square meter, was found in the 3-year restored meadow and was relatively lower in the 21-year restored meadow. Also, plant densities in 14-, 17-, 21-year restored and reference meadows were similar. The aboveground biomass was the highest in 21-year restored meadows, followed by those in 17- and 3-year restored meadows. The belowground biomasses were generally higher in older meadows, although there was no significant difference in biomass among the 5-, 9- and 14-year restored meadows. The total biomass was the lowest in the 3-year restored wetland and the highest in 21year restored meadows. Overall, the biomass of vegetation in 21-year restored meadow exceeded that of the reference meadow. Similarly, root/shoot ratios in restored meadows gradually increased in older restored meadows.

The highest diversity was observed in the 3-year restored community (Table 3 ). Shannon diversity index decreased significantly in older meadows, being close to that of the reference site. The diversity indices of 21-year restored and reference meadow were similar. The Richness index was the highest in 3- and 5-year old meadows. The reference meadow had the lowest Richness index compared to restored meadows. Even though the Evenness index of the restored meadows decreased in older meadows, the value changed slightly. There was no significant difference among 17-, 21-year restored and reference meadows.

\section{Relationships between community properties and soil moisture}

Correlation analyses showed that plant height, coverage and root/shoot ratio were positively correlated with soil water content at the soil depth of $0-10 \mathrm{~cm}(\mathrm{R}=0.76,0.948$ and 0.836 , respectively), but there was no significant correlation observed at the soil depth of 10-20 and 20-30 cm (Table 4). There was a negative correlation between plant density and soil water content at the soil depth of $0-10 \mathrm{~cm}(\mathrm{R}=-0.968)$.

The Shannon diversity, Richness and Evenness showed significant and negative linear correlations with soil water content at the soil depth of $0-10 \mathrm{~cm}(\mathrm{R}=-0.869,-0.841$, 0.826 , respectively, Fig. 2a, d and g). However, there was no 
Table 3. Means of plant community variables in the restored and reference meadows. Notes: Different letters indicate significant differences in community properties among the meadows $(\mathrm{P}<0.05)$.

\begin{tabular}{|c|c|c|c|c|c|c|c|}
\hline \multirow[b]{2}{*}{ Community properties } & \multicolumn{7}{|c|}{ Meadows } \\
\hline & $\begin{array}{c}\text { 3-year } \\
\text { restoration } \\
\end{array}$ & $\begin{array}{c}\text {-year } \\
\text { restoration } \\
\end{array}$ & $\begin{array}{c}\text { 9-year } \\
\text { restoration } \\
\end{array}$ & $\begin{array}{c}14 \text {-year } \\
\text { restoration }\end{array}$ & $\begin{array}{c}\text { 17-year } \\
\text { restoration } \\
\end{array}$ & $\begin{array}{l}21-y e a r \\
\text { restoration }\end{array}$ & Reference \\
\hline Height $(\mathrm{cm})$ & $25.7 \mathrm{a}$ & $43.3 b$ & $42.5 b$ & $42.4 b$ & $62.3 \mathrm{c}$ & $86.2 d$ & $82.5 \mathrm{~d}$ \\
\hline Coverage $(\%)$ & $38.3 \mathrm{a}$ & $55.7 \mathrm{~b}$ & $65.7 \mathrm{c}$ & $72.3 \mathrm{c}$ & $81.5 \mathrm{~d}$ & $91.3 \mathrm{e}$ & $86.3 \mathrm{de}$ \\
\hline Density (No. $\mathrm{m}^{-2}$ ) & $1714 d$ & $1243 c$ & $931 b$ & $727 \mathrm{a}$ & $579 \mathrm{a}$ & $575 a$ & $722 a$ \\
\hline $\begin{array}{l}\text { Above-ground biomass } \\
\left(\mathrm{g} \mathrm{m}^{-2}\right)\end{array}$ & $203.3 b c$ & $166.3 \mathrm{ab}$ & $161.4 \mathrm{a}$ & $192.6 \mathrm{ab}$ & $236.6 \mathrm{c}$ & $397.9 \mathrm{e}$ & $280.7 d$ \\
\hline $\begin{array}{l}\text { Belowground biomass } \\
\left(\mathrm{g} \mathrm{m}^{-2}\right)\end{array}$ & $219.4 \mathrm{a}$ & $572 \mathrm{ab}$ & $803.5 b$ & $795.4 b$ & $1624.2 \mathrm{c}$ & $3656.4 \mathrm{e}$ & $2643.6 \mathrm{~d}$ \\
\hline Total biomass $\left(\mathrm{g} \mathrm{m}^{-2}\right)$ & $422.6 \mathrm{a}$ & $738.3 \mathrm{ab}$ & $964.8 \mathrm{~b}$ & $988.1 \mathrm{~b}$ & $1860.8 \mathrm{c}$ & $4054.2 \mathrm{e}$ & $2924.3 d$ \\
\hline Root/shoot ratio & $1.1 \mathrm{a}$ & $3.6 \mathrm{~b}$ & $5 \mathrm{bc}$ & $4.2 \mathrm{~b}$ & $6.9 \mathrm{c}$ & $9.2 \mathrm{~d}$ & $9.4 \mathrm{~d}$ \\
\hline $\begin{array}{l}\text { Shannon diversity index } \\
(H)\end{array}$ & $2.68 \mathrm{e}$ & $2.57 \mathrm{de}$ & $2.38 \mathrm{~cd}$ & $2.3 \mathrm{c}$ & $2.19 \mathrm{bc}$ & $1.99 \mathrm{ab}$ & $1.77 \mathrm{a}$ \\
\hline Richness index $(R)$ & $2.43 \mathrm{~d}$ & $2.32 \mathrm{~d}$ & $2.09 \mathrm{c}$ & $1.91 b c$ & $1.79 \mathrm{~b}$ & $1.73 b$ & $1.15 \mathrm{a}$ \\
\hline Evenness index $(E)$ & $0.87 \mathrm{c}$ & $0.87 \mathrm{c}$ & $0.84 b c$ & $0.83 b c$ & $0.81 \mathrm{abc}$ & $0.75 \mathrm{a}$ & $0.77 \mathrm{ab}$ \\
\hline
\end{tabular}

Table 4. Correlations between community properties and soil moisture at different soil depth. ${ }^{*}$ Correlation is significant at the 0.05 level (two-tailed). ${ }^{* *}$ Correlation is significant at the 0.01 level (two-tailed).

\begin{tabular}{lccc}
\hline & \multicolumn{3}{c}{ Soil water content (\%) } \\
\cline { 2 - 4 } & $0-10 \mathrm{~cm}$ & $10-20 \mathrm{~cm}$ & $20-30 \mathrm{~cm}$ \\
\hline Height $(\mathrm{cm})$ & $0.76^{*}$ & 0.154 & 0.217 \\
Coverage (\%) & $0.948^{* *}$ & 0.518 & 0.557 \\
Density (No. $\left.{ }^{-2}\right)$ & $-0.968^{* *}$ & -0.711 & -0.725 \\
Above-ground biomass $\left(\mathrm{g} \mathrm{m}^{-2}\right)$ & 0.529 & -0.198 & 0.090 \\
Belowground biomass $\left(\mathrm{g} \mathrm{m}^{-2}\right)$ & 0.704 & 0.026 & 0.194 \\
Total biomass $\left(\mathrm{g} \mathrm{m}^{-2}\right)$ & 0.695 & 0.012 & 0.188 \\
Root/shoot ratio & $0.836^{*}$ & 0.306 & 0.289 \\
\hline
\end{tabular}

significant correlation between diversity and soil water content at other soil depths (10-20 cm and 20-40 cm).

\section{Discussion}

The conversion of arable lands into grasslands might result in some constraints for ecological restoration because of possible destruction of seed banks during cultivation and changes of soil condition (Manchester et al. 1998). In this study, the plant community of the abandoned arable lands was characterized by ruderal plants gradually being succeeded by meadow and wet meadow species, such as grasses and sedges, as restoration time passed. Simultaneously, high diversity of plants was observed in early restored meadows, which confirmed our first hypothesis. These results were supported by a former study where a perennial grass was more dominant in later stages of restored grasslands compared to recently restored ones (Deák et al. 2015). This could likely be explained by biotic filtering contributing to the diversity changes in restored ecosystems (Kelemen et al. 2013). The high variability of plant communities and the high number of co-occurring species are probably due to random establishment processes provided not only by seed banks but also by spatial dispersal (Deák et al. 2015). High plant diversity was likely also attributed to the undeveloped biotic interactions and also the lack of late-successional competitors which hindered the establishment of subordinate species by biotic filtering (Wellstein et al. 2014).

A previous study showed that some species in natural wetlands never recovered, even in wetlands passively restored for 12 years (Mulhouse and Galatowitsch 2003). Furthermore, it was difficult for vegetation of abandoned farmlands to return to their original levels through natural succession even after 60 years or more (Stroh et al. 2012). However, results of the increasing similarity between restored meadows and the reference site demonstrated that natural succession for roughly two decades could form species composition and construct community structure like that of the target community. This 
$0-10 \mathrm{~cm}$
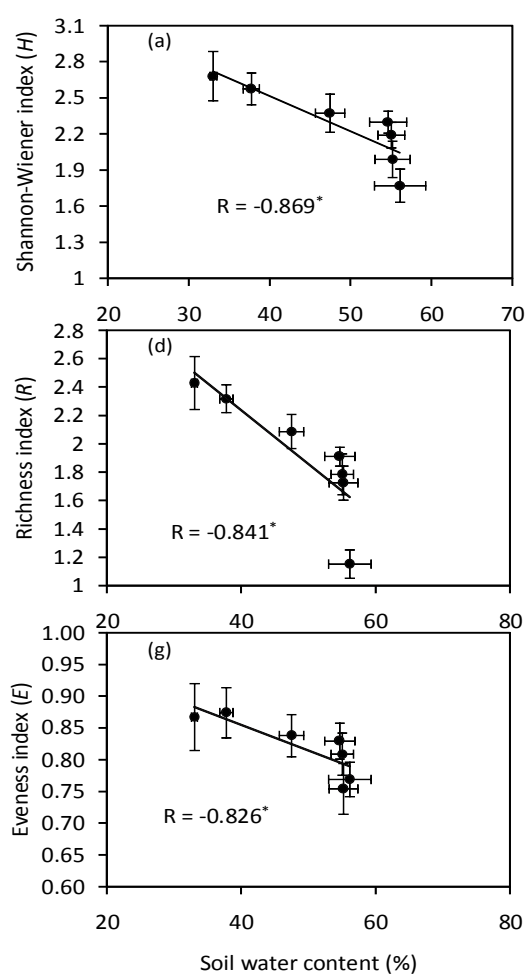

$10-20 \mathrm{~cm}$
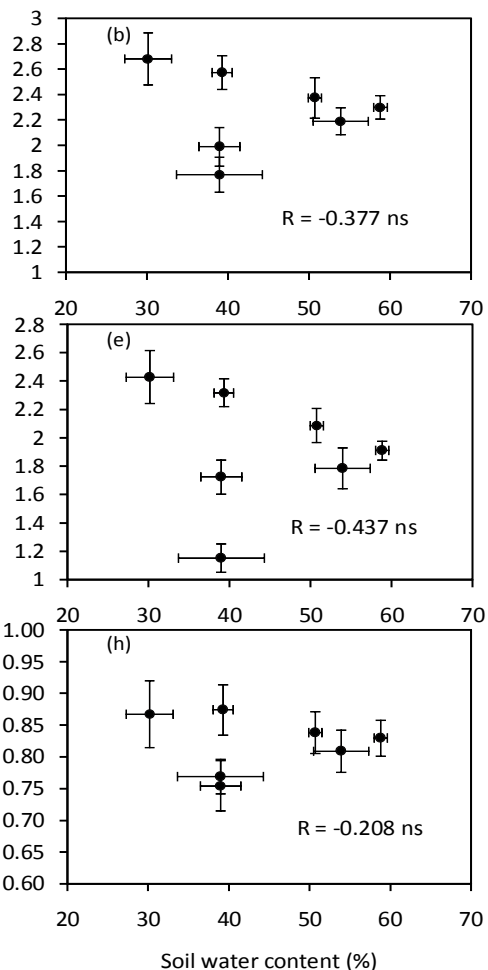

$20-40 \mathrm{~cm}$
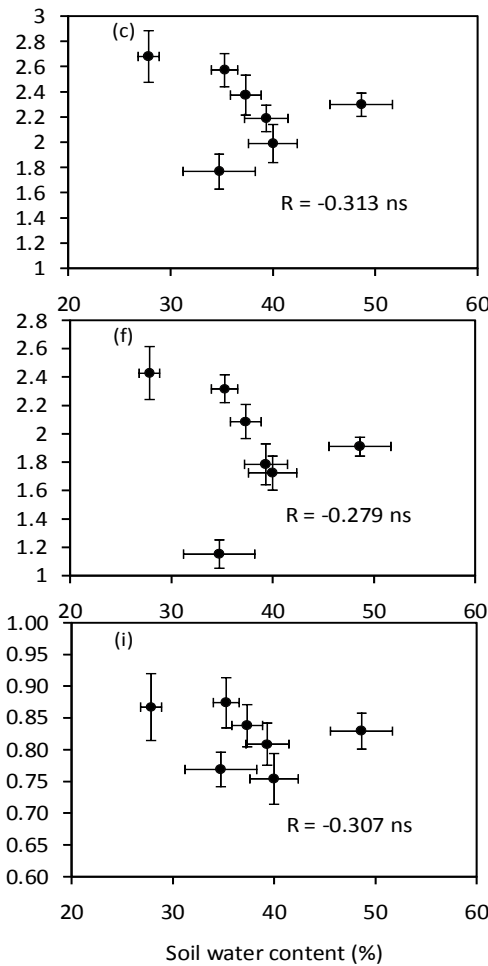

Figure 2. Relationships between soil water content in three soil depths (0-10 cm, 20-30 cm and 20-40 cm) and plant diversity (ShannonWinner index, richness index and evenness index). Lines show predicted values from the best significant regression model. The vertical bars are standard errors of the means of diversity indices, and the horizontal bars are standard errors of the means of soil water content. * Correlation is significant at the 0.05 level, ns indicates no significant correlation.

result was consistent with former studies which reported that similarity between restored and reference sites increased with the extension of restoration time (Vécrin et al. 2002, Guo et al. 2017). Thus, high similarity of restored meadows to reference site in terms of species composition was considered as restoration target.

In this study, the vegetation in the restored meadow after 21 years of restoration was more productive than vegetation in meadows in early succession stage as well as the reference site. Plant height, coverage, aboveground and belowground biomass generally increased over time. This recovery pattern, a linear increase and recovery of biomass, is also consistent with vegetation recovery across a chronosequence of restored wetlands in central Nebraska (Meyer et al. 2008). In addition, plants tended to allocate more biomass in belowground than in aboveground parts across time. This result is in agreement with the results obtained for restored wetlands (Mitsch and Gosselink 2000). This phenomenon is explained by the fact that allocating more biomass to belowground parts is beneficial for resource use in changed environments during natural succession (Mueller et al. 2013). Simultaneously, the plant density in the community decreased across restoration time, implying that there is inter- and intraspecific competition and density-dependent mortality when meadow species, such as $C$. angustifolia and Carex spp, become dominant under favorable water conditions. Moreover, a dense stand of meadow and wet meadow plants can reduce access to light for seedlings of other species, thus limiting plants density. The development of these species would enhance their competitiveness and resulted in an overall decrease of species richness and diversity. Conversely, intensive competition for nutrients could explain the increase in root biomass production in older restored meadows.

The dynamic patterns of soil water provide essential information to assess wetland restoration success ( $\mathrm{Li}$ et al. 2011). Recovery of soil properties can provide the foundation for the return of ecosystem function (Shaffer and Ernst 1999), and soil water condition directly impacts spatial distribution patterns of vegetation communities in restored ecosystems (Li et al. 2011). We found that plant height, coverage, and root/shoot ratio were significantly and positively related to the surface soil water content $(0-10 \mathrm{~cm})$ in studied meadows on the Sanjiang Plain, which support our second hypothesis. This means that surface soil water content influenced not only community properties, but also biomass allocation in aboveand belowground parts. This is consistent with a former study in which biomass allocation was strongly influenced by water conditions in riparian wetlands (Hefting et al. 2004). Also, it was reported that plant species adapted to variation in the environment by capturing resources, such as water, to maximize their growth rate (Bloom et al. 1985), partially accounting for the critical effect of surface soil water content on plant height. Our result is also confirmed in a related study in which positive relationship was detected between soil water content 
and coverage in restored grasslands (Liu et al. 2015). These positive interactions between water condition in surface soil and plant community properties might be ascribed to the runoff processes regulated by plant cover (Vásquez-Méndez et al. 2010) and micro-environment reformed canopy coverage, thus promoting plant growth (Bever 2003).

Notably, we found that plant diversity (Shannon index, Richness index and Evenness index) were closely correlated with soil water content at the soil depth of $0-10 \mathrm{~cm}$, which further confirmed our second hypothesis. The result is consistent with a published result that the species richness of community decreased with improvement of hydrological conditions (Wang et al. 2010). This is also supported by another study reporting that species richness significantly decreased with soil water content at the surface soil in alpine wetland ecosystem (Wu et al. 2013). Nonetheless, this result is in contrast to the previous study that plant diversity was positively correlated to soil water content at the soil depth of $0-10 \mathrm{~cm}$ in semiarid grassland (Wu et al. 2014). Soil water regime might explain this divergence. Soil water determined the growth and relative superiority of dominant species, which are adaptable in higher moisture habitats. Accordingly, the restored meadows properly recovered their intrinsic hydrologic functions and developed native plant communities. In turn, plant species diversity had positive effects on controlling surface runoff and preventing the degradation of ecosystems (Wang 2004). Thus, hydrology recovery is of importance in regulating plant community and species diversity in restored meadow ecosystems, although plant species did not influence soil moisture in case of soil saturation or flooding. The plant-soil feedbacks play an important role in determining and potentially influencing species coexistence in the restored meadows. Moreover, the soil properties vary temporally and spatially during ecosystem succession. Studies on soil nutrient heterogeneity modulating plant community assembly across successional ages should be further investigated.

Acknowledgements: This work was supported by the National Natural Science Foundation of China (41871102; 41601053; 41771106) and the National Key R\&D Program of China (2016YFC0500403).

\section{References}

Balata, D., L. Piazzi and F. Cinelli. 2004. A comparison among assemblages in areas invaded by Caulerpa taxifolia and C. racemosa on a subtidal Mediterranean rocky bottom. Mar. Ecol. 25(1):1-13

Baldwin, A.H., M.S. Egnotovich and E. Clarke. 2001. Hydrologic change and vegetation of tidal freshwater marshes: field, greenhouse, and seed-bank experiments. Wetlands 21:519-532.

Bever, D.J. 2003. Soil community feedback and the coexistence of competitors: conceptual frameworks and empirical tests. New Phytol. 157:465-473.

Biederman, L.A. and S.G. Whisenant. 2011. Using mounds to create microtopography alters plant community development early in restoration. Restor. Ecol. 19:53-61.
Bloom, A.J., F.S. Chapin and H.A. Mooney. 1985. Resource limitation in plants - an economic analogy. Annu. Rev. Ecol. Syst. 16:363-392.

Casanova, M.T. and M.A. Brock. 2000. How do depth, duration and frequency of flooding influence the establishment of wetland plant communities? Plant Ecol. 147:237-250.

De Steven, D. and M.M. Toner. 2004. Vegetation of upper coastal plain depression wetlands: environmental templates and wetland dynamics within a landscape framework. Wetlands 24:23-42.

De Steven, D., R.R. Sharitz and C.D. Barton. 2010. Ecological outcomes and evaluation of success in passively restored Southeastern depressional wetlands. Wetlands 30:1129-1140.

Deák, B., O. Valkó, P. Török, A. Kelemen, T. Miglécz, S. Szabó, G. Szabó and B. Tóthmérész. 2015. Micro-topographic heterogeneity increases plant diversity in old stages of restored grasslands. Basic Appl. Ecol. 16:291-299.

Editorial Committee of Flora of China. 2004. Flora of China. Science Press, Beijing.

Ellison, A.M. and B.L. Bedford. 1995. Response of a wetland vascular plant community to disturbance: a simulation study. Ecol. Appl. 5:109-123.

Ewing, K. 2002. Mounding as a technique for restoration of prairie on a capped landfill in the Puget Sound lowlands. Restor. Ecol. 10:289-296.

Grootjans, A.P., L.F.M. Fresco, C.C. de Leeuw and P.C. Schipper. 1996. Degeneration of species-rich Calthion palustris hay meadows; some considerations on the community concept. J. Veg. Sci. 7:185-194.

Guo, J., H. Jiang, H. Bian, L. Sheng, C. He and Y. Gao. 2017. Natural succession is a feasible approach for cultivated peatland restoration in Northeast China. Ecol. Eng. 104: 39-44.

Härdtle, W., B. Redecker, T. Assmann and H. Meyer. 2005. Vegetation responses to environmental conditions in floodplain grasslands: prerequisites for preserving plant species diversity. Basic Appl. Ecol. 7:280-288.

Hedberg, P., W. Kotowski, P. Saetre, K. Mälson, H. Rydin and S. Sundberg. 2012. Vegetation recovery after multiple-site experimental fen restorations. Biol. Conserv. 147:60-67.

Hefting, M., J.C. Clément, D. Dowrick, A.C. Cosandey, S. Bernal, C. Cimpian, A. Tatur, T.P. Burt and G. Pinay. 2004. Water table elevation controls on soil nitrogen cycling in riparian wetlands along a European climatic gradient. Biogeochemistry 67(1):113134.

Heisler-White, J.L., A.K. Knapp and E.F. Kelly. 2008. Increasing precipitation event size increases aboveground net primary productivity in a semi-arid grassland. Oecologia 158:129-140.

Huang, N., Z. Wang, D. Liu and Z. Niu. 2010. Selecting sites for converting farmlands to wetlands in the Sanjiang Plain, Northeast China, based on remote sensing and GIS. Environ. Manage. 46:790-800.

Johnson, W.C., S.E. Boettcher, K.A. Poiani and G. Guntenspergen. 2004. Influence of weather extremes on the water levels of glaciated prairie wetlands. Wetlands 24:385-398.

Kelemen, A., P. Török, O. Valkó, T. Miglécz and B. Tóthmérész. 2013. Mechanisms shaping plant biomass and species richness: Plant strategies and litter effect in alkali and loess grasslands. $J$. Veg. Sci. 24:1195-1203.

Kirk, J.A., W.R. Wise and J.J. Delfino. 2004. Water budget and cost effectiveness analysis of wetland restoration alternatives: a case study of Levy Prairie, Alachua County, Florida. Ecol. Eng. $22: 43-60$. 
Konar, M., M.J. Todd, R. Muneepeerakul, A. Rinaldo and I. Rodriguez-Iturbe. 2013. Hydrology as a driver of biodiversity: controls on carrying capacity, niche formation, and dispersal. Adv. Water Resour. 51:317-325.

Li, H.Y. and W.F. Wang. 2005. Profound significance for converting farmland to wetland in the Sanjiang Plain. Modernizing Agr. 2:1-3. (in Chinese)

Li, S., D. Zhou, Z. Luan, Y. Pan and C. Jiao. 2011. Quantitative simulation on soil moisture contents of two typical vegetation communities in Sanjiang Plain, China. Chin. Geogr. Sci. 21:723-733.

Liu, M., G. Liu and X. Zheng. 2015. Spatial pattern changes of biomass, litterfall and coverage with environmental factors across temperate grassland subjected to various management practices. Landscape Ecol. 30(3): 477-486.

Loheide, S.P. and S.M. Gorelick. 2007. Riparian hydroecology: A coupled model of the observed interactions between groundwater flow and meadow vegetation patterning. Water Resour. Res 43: W07414.

Manchester, S., J.O. Treweek, O. Mountford, R. Pywell and T. Sparks. 1998. Restoration of a target wet grassland community on exarable land. In: C.B. Joyce and P.M. Wade (eds.), European Wet Grasslands: Biodiversity, Management and Restoration. Wiley, Chichester, UK.

Matthews, J.W., G. Spyreas and A.G. Endress. 2009. Trajectories of vegetation based indicators used to assess wetland restoration progress. Ecol. Appl. 19:2093-2107.

Meyer, C.K., S.G. Baer and M.R. Whiles. 2008. Ecosystem recovery across a chronosequence of restored wetlands in the Platte River Valley. Ecosystems 11:193-208.

Mitsch, W.J. and J.G. Gosselink. 2000. Wetlands. John Wiley \& Sons, New York.

Mueller, K.E., D. Tilman, A. Fornara and S.E. Hobbie. 2013. Root depth distribution and the diversity-productivity relationship in a long-term grassland experiment. Ecology 94(4):787-793.

Mulhouse, J.M. and S.M. Galatowitsch. 2003. Revegetation of prairie pothole wetlands in the mid-continental US: twelve years post-reflooding. Plant Ecol. 169:143-159.

Shaffer, P.W. and T.L. Ernst. 1999. Distribution of soil organic matter in freshwater emergent/open water wetlands in the Portland, Oregon, Metropolitan Area. Wetlands 19:505-516.

Stroh, P.A., F.M.R. Hughes, T.H. Sparks and J.O. Mountford. 2012. The influence of time on the soil seed bank and vegetation across a landscape-scale wetland restoration project. Restor. Ecol. 20:103-112.

Suding, K.N., K.L. Gross and G.R. Houseman. 2004. Alternative states and positive feedbacks in restoration ecology. Trends Ecol. Evol. 19: 46-53.
Toogood, S.E., C.B. Joyce and S. Waite. 2008. Response of floodplain grassland plant communities to altered water regimes. Plant Ecol. 197(2):285-298.

Toth, L.A. 2010. Unrealized expectations for restoration of a floodplain plant community. Restor. Ecol. 18:810-819.

Valkó, O., B. Deák, P. Török, A. Kelemen, T. Miglécz and B Tóthmérész. 2017. Filling up the gaps-Passive restoration does work on linear landscape elements. Ecol. Eng. 102:501-508.

Vásquez-Méndez, R., E. Ventura-Ramos, K. Oleschko, L. HernándezSandoval, J.F. Parrot and M.A. Nearing. 2010. Soil erosion and runoff in different vegetation patches from semiarid Central Mexico. Catena 80:162-169.

Vécrin, M.P., R. Van Diggelen, F. Grévilliot and S. Muller. 2002. Restoration of species-rich flood-plain meadows from abandoned arable fields in NE France. Appl. Veg. Sci. 5(2):263-270.

Wang, L., C. Song, J. Hu and T. Yang. 2010. Response of regeneration diversity of Carex lasiocarpa community to different water levels in Sanjiang Plain, China. Chin. Geogr. Sci. 20(1):37-42.

Wang, Z.H. 2004. Relationship between plant species diversity and soil erosion on different secondary succession phases of a semihumid evergreen broad-leaved forest. In: Proceedings of the $13^{\text {th }}$ International soil conservation organization conference, Brisbane, paper No. 990.

Wang, Z.,B. Zhang, S. Zhang, X. Li, D. Liu, K. Song, J. Li, F. Li and H. Duan. 2006. Changes of land use and of ecosystem service values in Sanjiang Plain, Northeast China. Environ. Monit. Assess. 112(1-3): 69-91.

Wellstein, C.,G. Campetella, F. Spada, S. Chelli, L. Mucina, R. Canullo and S. Bartha. 2014. Context-dependent assembly rules and the role of dominating grasses in semi-natural abandoned sub-Mediterranean grasslands. Agr. Ecosyst. Environ. 182:113122.

Wu, G.L., G.H. Ren, D. Wang, Z.H. Shi and D. Warrington. 2013 Above-and belowground response to soil water change in an alpine wetland ecosystem on the Qinghai-Tibetan Plateau, China. J. Hydrol. 476:120-127.

Wu, G.L., Z.N. Zhang, D. Wang, Z.H. Shi and Y.J. Zhu. 2014 Interactions of soil water content heterogeneity and species diversity patterns in semi-arid steppes on the Loess Plateau of China. J. Hydrol. 519:1362-1367.

Zhao, K.Y., Y.J. Luo, D.M. Zhou and X.L. Zhou. 2008. A study of current status and conservation of threatened wetland ecological environment in Sanjiang Plain. J. Nat. Resour. 23(5):790-796. (in Chinese).

Received May 30, 2018

Revised November 15,2018 Accepted December 20, 2018 